Karolina Kremens

Uniwersytet Wrocławski

karolina.kremens@uwr.edu.pl

\title{
Model postępowania dyscyplinarnego wobec prokuratorów - wybrane zagadnienia
}

\author{
Model of disciplinary proceedings against prosecutors - selected issues
}

\begin{abstract}
The article discusses possible models of disciplinary proceedings against prosecutors in Poland. In the first, the so-called "corporate" model, the disciplinary commissions of both instances are composed only of prosecutors. In the second, the so-called "mixed” model, in the first instance the disciplinary commission, composed only of prosecutors, delivers the judgment and appeal goes to the court. The last model introduces single disciplinary proceedings for judges, prosecutors, advocates, legal advisors and notaries. In this model cases are heard by courts with a right to appeal the judgment to the Supreme Court. The article seeks to answer the question of which model better suits disciplinary proceedings against prosecutors in Poland.
\end{abstract}

Keywords: disciplinary proceedings, prosecutor, organ conducting proceedings

Słowa kluczowe: postępowanie dyscyplinarne, prokurator, organ prowadzący postępowanie

\section{Wprowadzenie}

Odpowiedzialność dyscyplinarna prokuratorów stanowi jeden z rodzajów odpowiedzialności prawnej o charakterze quasi-karnym, znajdującym swe źródło w sferze prawa represyjnego ${ }^{1}$. Możliwość pociągnięcia do odpowiedzialności prokuratora w drodze postępowania dyscyplinarnego, za czyny pozostające w związku ze spra-

$1 \quad$ Zob. P. Czarnecki, Postępowanie dyscyplinarne wobec osób wykonujących prawnicze zawody zaufania publicznego, Warszawa 2013, s. 61-158 - wyczerpująco na temat definicji odpowiedzialności dyscyplinarnej oraz rozważania dotyczące relacji pomiędzy odpowiedzialnością dyscyplinarną a innymi formami odpowiedzialności osób wykonujących zawody prawnicze. Zob. także ogólnie na temat odpowiedzialności prokuratorów: W. Kozielewicz, Odpowiedzialność dyscyplinarna sędziów, prokuratorów, adwokatów, radców prawnych i notariuszy, Warszawa 2012. 
wowaną przez niego funkcją, stanowi jedną z gwarancji niezależności prokuratury². Pomimo wejścia w życie nowej ustawy z 2016 r., ${ }^{3}$ zmiany w zakresie postępowania dyscyplinarnego nią dokonane, pomijając pewne pozytywne wyjątki ${ }^{4}$, nie odpowiedziały na podstawowe zastrzeżenia dotyczące kształtu odpowiedzialności dyscyplinarnej prokuratorów formułowane jeszcze na gruncie uprzednio obowiązujących przepisów ${ }^{5}$.

Nowa ustawa nie zmieniła uregulowań dotyczących modelu sądownictwa dyscyplinarnego w zakresie organów prowadzących postępowanie, tym samym powielając dotychczasowy model sądownictwa dyscyplinarnego funkcjonujący w oparciu o ustawę z 1985 r. ${ }^{6}$ Ze względu na fakt, iż w przeszłości proponowano różne rozwiązania w tym zakresie, warto przyjrzeć się im z bliska. Możliwość wprowadzenia innego kształtu sądownictwa dyscyplinarnego w dalszym ciągu budzi spore kontrowersje, przede wszystkim ze względu na możliwość odebrania prokuratorom wyłącznej kompetencji do orzekania dyscyplinarnego w pierwszej i drugiej instancji w sprawach ich dotyczących i przeniesienia tych uprawnień w całości lub w części do sądownictwa powszechnego. Dlatego też celem niniejszego opracowania będzie omówienie możliwych modeli postępowania dyscyplinarnego wobec prokuratorów według kryterium organu prowadzącego postępowanie dyscyplinarne i udzielenie odpowiedzi na pytanie, który z nich lepiej odpowiada na istniejące problemy postępowań dyscyplinarnych wobec prokuratorów. Inne elementy, nie mniej istotne dla modelu postępowania dyscyplinarnego, takie jak m.in. kompetencje Rzecznika Dyscyplinarnego, terminy przedawnienia czy możliwość zaskarżania orzeczeń dyscyplinarnych za pomocą kasacji lub względnie wznowienia postępowania, a także zagadnienie jawności postępowań, ze względów objętościowych pozostaną poza zakresem niniejszego opracowania.

\section{Modele sądownictwa dyscyplinarnego - uwagi ogólne}

Modeli postępowania dyscyplinarnego według kryterium organów orzekających w tym postępowaniu, na potrzeby niniejszego opracowania można wyróżnić trzy. Pierwszy z nich, obowiązujący obecnie, oddaje dwuinstancyjne są-

T. Demendecki, (w:) J. Bodio, G. Borkowski, T. Demendecki, Ustrój organów ochrony prawnej. Część szczegółowa, Wydanie 4, Warszawa 2013, s. 231.

3 Ustawa z dnia 28 stycznia 2016 r. Prawo o prokuraturze, Dz.U. poz. 178 (dalej jako: pr. prok).

$4 \quad$ Chodzi przede wszystkim o zapewnienie postulowanej od dawna jawności prokuratorskich postępowań dyscyplinarnych - zob. K. Kremens, Jawność prokuratorskich postępowań dyscyplinarnych, „Prokuratura i Prawo” 2015, nr 5, s. 128-142.

5 Zob. m.in. P. Kardas, Rola i miejsce prokuratury w systemie organów demokratycznego państwa prawnego. Kilka uwag o przesłankach determinujących założenia projektu ustawy o prokuraturze, „Prokuratura i Prawo” 2012, nr 9, s. 44; P. Czarnecki, Postępowanie dyscyplinarne..., op. cit., s. 435 oraz K. Kremens, Odpowiedzialność zawodowa prokuratorów, Warszawa 2010, s. 18-19. kuraturze (tekst jedn. Dz.U. z 2011 r. Nr 270, poz. 1599 ze zm.). W tym zakresie nowe Prawo o prokuraturze nie dokonało zmian. 
downictwo dyscyplinarne w ręce organów „korporacyjnych”, składających się wyłącznie z prokuratorów, z możliwością zaskarżenia wyroku drugiej instancji kasacją do Sądu Najwyższego.

Drugi z modeli, umownie określany jako „mieszany”, opisany w jednym ze zgłaszanych w przeszłości projektów ustawy Prawo o prokuraturze z dnia 20 lutego 2014 r. $^{8}$ zakładał rozpatrywanie spraw dyscyplinarnych w pierwszej instancji przez sąd „korporacyjny”, a w drugiej przez sąd powszechny (lub Sąd Najwyższy). W dalszej kolejności od orzeczenia przysługiwać miała kasacja do Sądu Najwyższego.

Trzeci model, zawarty w projekcie ustawy o postępowaniu dyscyplinarnym wobec osób wykonujących niektóre zawody prawnicze z 2013 r., ${ }^{9}$ zakładał wprowadzenie jednolitego sądownictwa dyscyplinarnego dla sędziów, prokuratorów, adwokatów, radców prawnych i notariuszy. W tym modelu w pierwszej instancji miały orzekać specjalnie utworzone wydziały dyscyplinarne w sądach apelacyjnych, a w drugiej instancji Sąd Najwyższy. Od orzeczeń drugiej instancji kasacja nie przysługiwała ${ }^{10}$.

Przykłady innych rozwiązań, które można określić mianem submodeli, możemy spotkać w innych ustawach. Na przykład w postępowaniu dyscyplinarnym komorników sądowych (zob. ustawa z dnia 29 sierpnia 1997 r. o komornikach sądowych i egzekucji, tekst jedn. Dz.U. z 2011 r. Nr 231, poz. 1376) przewiduje się rozpoznanie spraw w pierwszej instancji przez komisję dyscyplinarną, a w drugiej przez sąd okręgowy właściwy według siedziby kancelarii obwinionego komornika (art. 75 ust. 1-2) i równocześnie od wyroku zapadającego w drugiej instancji kasacja w ogóle nie przysługuje. Z kolei postępowanie dyscyplinarne doradców podatkowych (ustawa z dnia 5 lipca 1996 r. o doradztwie podatkowym, tekst jedn. Dz.U. z 2011 r. Nr 41, poz. 213) zakłada powierzenie dwuinstancyjnego postępowania dyscyplinarnego sądom „korporacyjnym” przy jednoczesnej możliwości złożenia odwołania do sądu powszechnego, tj. sądu apelacyjnego - sądu pracy i ubezpieczeń społecznych, właściwego ze względu na miejsce zamieszkania obwinionego (art. 75 ust. 1 ustawy o doradztwie podatkowym). W tym przypadku również nie przewidziano kasacji do Sądu Najwyższego.

Autorka ma świadomość umowności i pewnej nieadekwatności stosowania terminu „korporacyjny” wobec sądownictwa dyscyplinarnego tak prokuratorów, jak i sędziów. Jednakże ze względu na potoczne rozumienie tego zwrotu będzie on używany jako skrót myślowy dla potrzeb niniejszego opracowania.

8 Projekt ustawy Prawo o prokuraturze z dnia 20 lutego 2014 r. (dalej jako: proj. z 2014) dostępny na stronie internetowej http://legislacja.rcl.gov.pl/docs//2/52748/52767/dokument102521.pdf (data dostępu: 6.12.2016 r.).

9 Druk sejmowy nr 1202 (dalej jako: proj. jsd.) dostępny na stronie internetowej: http://orka.sejm.gov.pl/Druki7ka. nsf/0/3B6C514FACAC465AC1257B35005DBAED/\%24File/1202.pdf (data dostępu: 6.12.2016 r.).

10 Zob. art. 26 ust. 1 projektu jednolitego sądownictwa dyscyplinarnego. Ustęp 2 tego przepisu dopuszcza jedynie kasację Rzecznika Praw Obywatelskich od każdego prawomocnego orzeczenia sądu dyscyplinarnego kończącego postępowanie dyscyplinarne. 


\section{Model "korporacyjnego" sądownictwa dyscyplinarnego wobec prokuratorów}

Zgodnie z obowiązującą obecnie regulacją, w pierwszej instancji postępowania dyscyplinarne toczą się przed Sądami Dyscyplinarnymi, a w drugiej przed Odwoławczymi Sądami Dyscyplinarnymi (art. $145 \$ 1$ pr. prok.). Liczbę sądów dyscyplinarnych oraz ogólną liczbę członków sądów dyscyplinarnych ustala Krajowa Rada Prokuratury (art. $43 \$ 3$ pr. prok.). Sami sędziowie dyscyplinarni są natomiast wybierani spośród grona wszystkich prokuratorów przez zgromadzenia prokuratorów, tj. organy kolegialne usytuowane $w$ prokuraturach apelacyjnych oraz przez zebranie prokuratorów w Prokuraturze Krajowej (art. 45 i 47 pr. prok.). Skład sądu dyscyplinarnego wyznacza przewodniczący według listy wszystkich sędziów danego sądu, zgodnie z kolejnością wpływu spraw, z tym że w składzie sądu zasiada przynajmniej jeden prokurator z jednostki organizacyjnej prokuratury równorzędnej do tej, w której obwiniony pełnił służbę lub wykonywał czynności służbowe w chwili czynu (art. $147 \$ 1$ pr. prok. $)^{11}$.

Pełna „korporacyjność” prokuratorskiego sądownictwa dyscyplinarnego została złamana przez możliwość złożenia od prawomocnego orzeczenia dyscyplinarnego wydanego w drugiej instancji kasacji do Sądu Najwyższego (art. $163 \$ 1$ pr. prok.). Zakres kasacji jest szerszy niż ten, który określają przepisy procesu karnego ${ }^{12}$. Taki stan rzeczy, zdaniem Trybunału Konstytucyjnego, nie budzi wątpliwości i uznawany jest za wystarczającą kontrolę sądową orzeczeń dyscyplinarnych wydawanych wobec prokuratorów przez prokuratorskie sądy dyscyplinarne ${ }^{13}$.

\section{Model „mieszanego” sądownictwa dyscyplinarnego}

W uzasadnieniu do projektu z 2014 r. wskazano, że celem modelu „mieszanego” jest dążenie do „obiektywizacji rozstrzygnięć sądów dyscyplinarnych pierwszej instancji poprzez wprowadzenie kognicji sądów apelacyjnych”, albowiem model „korporacyjnego" sądownictwa dyscyplinarnego wyczerpał się ${ }^{14}$. Projekt ten zakładał

Odstępstwo od kolejności wpływu spraw możliwe jest tylko w wypadku choroby członka sądu lub z innej ważnej przyczyny, co należy zaznaczyć w zarządzeniu o wyznaczeniu rozprawy lub posiedzenia.

12 W postępowaniu karnym kasacja może być wniesiona tylko z powodu uchybień wymienionych w art. $439 \mathrm{kpk}$. (tzw. bezwzględne przyczyny odwoławcze) lub innego rażącego naruszenia prawa, jeżeli mogło mieć ono istotny wpływ na treść orzeczenia, natomiast nie może być wniesiona wyłącznie z powodu niewspółmierności kary (art. $523 \S 1 \mathrm{kpk}$.). Art. $163 \S 1$ pr. prok. stanowi natomiast, że kasacja może być wniesiona zarówno z powodu rażącego naruszenia prawa, jak i rażącej niewspółmierności kary dyscyplinarnej.

13 W wyroku TK z dnia 25 czerwca 2012 r., sygn. K 9/10, OTK-A 2012, nr 6, poz. 66, Trybunał Konstytucyjny stwierdzit, że „wyznaczony przez zaskarżone przepisy zakres sądowego postępowania kontrolnego w sprawach dyscyplinarnych jest zgodny z art. 45 ust. 1 Konstytucji. Trybunał uznał, że przyjęcie modelu kontroli, w którym kasacja może być wniesiona wyłącznie z powodu „rażącego naruszenia prawa” oraz „rażącej niewspółmierności kary dyscyplinarnej”, mieści się w granicach swobody stanowienia prawa przez ustawodawcę zwykłego oraz nie narusza zasady sprawiedliwego rozpatrzenia sprawy i wynikającego $z$ niej obowiązku odpowiedniego ukształtowania procedury sądowej".

14 Uzasadnienie proj. z 2014, s. 71. 
poważne zmiany w sądownictwie dyscyplinarnym wobec prokuratorów, a jego najważniejszym elementem było powierzenie sądownictwa dyscyplinarnego w drugiej instancji sądom apelacyjnym lub Sądowi Najwyższemu. Sądami pierwszej instancji w sprawach dyscyplinarnych miały stać się Sąd Dyscyplinarny w Prokuraturze Generalnej oraz sądy dyscyplinarne w prokuraturach apelacyjnych (art. $169 \$ 1$ proj. z 2014), w zależności od osoby obwinionego ${ }^{15}$. Zmiany miały objąć także decentralizację sądownictwa dyscyplinarnego w pierwszej instancji oraz modyfikację sposobu wyboru członków sądów dyscyplinarnych. Druga instancja orzecznictwa dyscyplinarnego wobec prokuratorów miała zostać przeniesiona do Sądu Najwyższego w sprawach rozpoznawanych w pierwszej instancji przez Sąd Dyscyplinarny w Prokuraturze Generalnej oraz do sądów apelacyjnych w sprawach rozpoznawanych w pierwszej instancji przez sądy dyscyplinarne w prokuraturach apelacyjnych (art. $169 \$ 2$ proj. z 2014). Właściwym miejscowo sądem apelacyjnym, będącym sądem dyscyplinarnym drugiej instancji miał być sąd, w którego obszarze właściwości orzekał sąd dyscyplinarny pierwszej instancji (art. $172 \$ 1$ proj. z 2014).

W skład Sądu Dyscyplinarnego w Prokuraturze Generalnej mieli wchodzić prokuratorzy Prokuratury Generalnej ${ }^{16}$ (art. $171 \$ 1$ proj. z 2014). W skład sądów dyscyplinarnych w prokuraturach apelacyjnych mieli wchodzić prokuratorzy tej prokuratury, a także prokuratorzy prokuratur okręgowych z obszaru właściwości tej prokuratury apelacyjnej, w liczbie odpowiadającej liczbie prokuratorów prokuratury apelacyjnej oraz prokuratorzy prokuratur rejonowych z obszaru właściwości tej prokuratury apelacyjnej w tej samej liczbie, wybierani przez zgromadzenie prokuratorów w prokuraturze apelacyjnej (art. $171 \$ 2$ proj. z 2014) ${ }^{17}$. Projekt wprowadzał także mieszany skład orzekający w każdej sprawie, co oznaczało, że w drodze losowania każdorazowo należało wyznaczyć sąd dyscyplinarny tak, aby znaleźli się w nim prokurator prokuratury apelacyjnej, prokurator prokuratury okręgowej i prokurator prokuratury rejonowej (art. $171 \$ 10$ proj. z 2014). Natomiast skład sądu dyscyplinarnego drugiej instancji wyznaczany miał być w drodze losowania, z listy wszystkich sędziów danego sądu, w składzie którego miał zasiadać przynajmniej jeden sędzia stale orzekający w sprawach karnych (art. $172 \$ 4$ proj. z 2014).

15 Sąd Najwyższy miał być powołany do rozpoznawania spraw przeciwko Prokuratorowi Generalnemu, prokuratorom Prokuratury Generalnej, Dyrektorowi Głównej Komisji, Dyrektorowi Biura Lustracyjnego, prokuratorom apelacyjnym i ich zastępcom, prokuratorom okręgowym i ich zastępcom, a także prokuratorom delegowanym do Prokuratury Generalnej, Ministerstwa Sprawiedliwości, Krajowej Szkoły Sądownictwa i Prokuratury, jeżeli przewinienia dyscyplinarnego dopuścili się w okresie delegowania. Z kolei sądy dyscyplinarne utworzone w prokuraturach apelacyjnych miały prowadzić postępowania wobec pozostałych prokuratorów (art. $170 \S 1$ proj. z 2014) zgodnie z właściwością miejscową odpowiadającą miejscu popełnienia czynu stanowiącego przedmiot postępowania przed sądem dyscyplinarnym (art. 170 § 2 proj. z 2014).

$16 \quad$ Z tego grona wyłączono Prokuratora Generalnego i jego zastępców oraz rzecznika dyscyplinarnego.

17 A nadto wybrani przez obradujące wspólnie Zgromadzenie Prokuratorów Głównej Komisji i Zgromadzenie Prokuratorów Biura Lustracyjnego prokuratorzy Instytutu Pamięci Narodowej, w liczbie odpowiadającej liczbie prokuratur apelacyjnych. Dyrektor Głównej Komisji wyznacza po jednym z wybranych prokuratorów do sądów dyscyplinarnych w poszczególnych prokuraturach apelacyjnych. 
Model ten wydawał się być najbliższy wymogom formułowanym w regulacjach prawnych o charakterze ponadnarodowym. Co prawda w Wytycznych ONZ z 1990 r. dotyczących roli prokuratorów ${ }^{18}$ nie określono, jaki organ powinien prowadzić postępowania dyscyplinarne wobec prokuratorów ${ }^{19}$. Jednakże już w Rekomendacji Rady Europy z 2000 roku $^{20}$ oraz w tzw. Memorandum wyjaśniającym dołączonym do Rekomendacji ${ }^{21}$ przyjęto, że orzeczenia w postępowaniu dyscyplinarnym w pierwszej instancji powinien rozpoznawać sąd złożony z prokuratorów, podczas gdy druga instancja miałaby posiadać przymiot niezależności i niezawisłości, co zapewnić może, jak się wydaje, jedynie organ sądowy.

\section{Model jednolitego sądownictwa dyscyplinarnego dla osób wykonu- jących niektóre zawody prawnicze}

Projektowi jednolitego sądownictwa dyscyplinarnego (dalej - jsd.) należy w tym miejscu poświęcić chwilę uwagi. Projekt ten w swojej pierwotnej wersji został przedłożony Sejmowi V kadencji jako projekt rządowy w 2006 r. $^{22}$ Wywołał on dyskusję w środowisku, wzbudzając wiele kontrowersji i spotykając się z miażdżącą krytyką ${ }^{23}$. Głównym zarzutem kierowanym pod adresem projektu była jego niekonstytucyjność, tj. niezgodność z art. 17 Konstytucji i wynikającą z niej zasadą powierzenia sa-

18 Art. 21 i 22 Wytycznych dotyczących roli prokuratorów (Guidelines on the Role of Prosecutors) przyjęte na VIII Kongresie Organizacji Narodów Zjednoczonych o zapobieganiu przestępczości i traktowaniu przestępców, Hawana 27 sierpnia - 7 września 1990 r., dostępne w języku angielskim na stronie internetowej http://www.ohchr. org/EN/Professionallnterest/Pages/RoleOfProsecutors.aspx (data dostępu: 6.12.2016 r.).

19 Za jedyną wskazówkę można uznać stwierdzenie, że postępowanie dyscyplinarne powinno gwarantować podjęcie obiektywnej oceny i decyzji (objective evaluation and decision), co przemawia na korzyść prowadzenia prokuratorskich postępowań dyscyplinarnych przez sędziów, którzy gwarantują najdalej idący obiektywizm ze względu na walor niezawisłości i niezależności przypisany temu urzędowi. Inne stwierdzenie zawarte w Wytycznych wskazuje, że postępowanie odwoławcze powinno mieć niezależny charakter (independent review), co również należy interpretować, iż także w tym przypadku powinien być to organ sądowy.

20 Zasada 5e Rekomendacji Rec (2000) 19 przyjętej przez Komitet Ministrów Rady Europy 6 października 2000 r. Rola prokuratury w systemie wymiaru sprawiedliwości w sprawach karnych (The Role of the Public Prosecution in the Criminal Justice System), https://wcd.coe.int/ViewDoc.jsp?id=376859\&Site=CM\# (data dostępu: 6.12.2016 r.).

21 Memorandum wyjaśniające (Explanatory Memorandum) do Rekomendacji RE Rec (2000)19, s. 7, https://wcd. coe.int/com.instranet.InstraServlet?command=com.instranet.CmdBlobGet\&InstranetImage=1465390\&SecMo$\mathrm{de}=1 \&$ Docld=838058\&Usage=2 (data dostępu: 6.12.2016 r.) (wskazano, iż obowiązek rozpoznania sprawy dyscyplinarnej w drugiej instancji przez niezależny i niezawisły organ nie dyskwalifikuje w żaden sposób możliwości rozpoznania sprawy w pierwszej instancji przez organ o charakterze administracyjnym albo hierarchicznym).

22 Zob. druk sejmowy $\mathrm{nr} 970 \mathrm{~V}$ Kadencji Sejmu, http://orka.sejm.gov.pl/Druki5ka.nsf/0/CCCC0111D05A3488C12571EF004C5803/\$file/970.pdf (data dostępu: 6.12.2016 r.).

23 P. Czarnecki, Postępowanie dyscyplinarne..., op. cit., s. 404-417 - zbiorczo prezentuje stanowisko przedstawicieli wszystkich zawodów prawniczych wobec projektu. Zob. także niektóre głosy w dyskusji nad projektem: A. Bojańczyk, W sprawie dwóch rozwiązań procesowych projektu ustawy o nowym ustroju dyscyplinarnym niektórych zawodów prawniczych, „Palestra” 2007, nr 9/10; K.K. Świeczkowski, Postępowanie dyscyplinarne wobec osób wykonujących zawody prawnicze, „Prokurator” 2006, nr 3. Zob. także opinie do projektu z 2006 r. m.in. P. Winczorek, T. Stawecki, Opinia prawna w sprawie zgodności z Konstytucją RP projektu ustawy o postępowaniu dyscyplinarnym wobec osób wykonujących niektóre zawody prawnicze z dnia 7 marca 2006 r. oraz A. Bojańczyk, Opinia do projektu ustawy o postępowaniu dyscyplinarnym wobec osób wykonujących niektóre zawody prawnicze (druk sejmowy nr 970) z dnia 14 sierpnia 2007 r. http://orka.sejm.gov.pl/IEKSBAS.nsf/0/C125728000417C20C125734600430931?OpenDocument (data dostępu: 6.12.2016 r.). 
morządom pieczy nad wykonywaniem zawodów zaufania publicznego. W związku z zakończeniem kadencji Sejmu prace nad tym projektem zostały przerwane. Powrócił on jednak w dniu 29 sierpnia 2012 r., jako projekt poselski klubu parlamentarnego Solidarnej Polski w VII kadencji sejmu ${ }^{24}$ i został wycofany przez wnioskodawcę w dniu 4 lutego 2013 r. ${ }^{25}$ tylko po to, aby powrócić już cztery dni później jako projekt zarejestrowany jako Druk nr 1202. Został on następnie skierowany do pierwszego czytania. Projekt zawierał identyczny model postępowania, ustrój organów i zasad postępowania, jak przedstawiony pierwotnie, natomiast nie uwzględniał uwag złożonych wobec projektu i nie miał wielkich szans, aby stać się ustawą ${ }^{26}$. Poparcie dla projektu zostało wycofane w dniu 14 grudnia 2014 r. jeszcze przed drugim czytaniem ${ }^{27}$.

Pomimo, jak się wydaje, braku możliwości wprowadzenia w chwili obecnej takiego rozwiązania w związku z poważnymi wątpliwościami natury konstytucyjnej ${ }^{28}$, warto projekt ten przeanalizować. Proponowano w nim wprowadzenie jednolitego mechanizmu orzekania w sprawach dyscyplinarnych dla zawodów prawniczych, takich jak sędziowie sądów powszechnych i prokuratorzy powszechnych jednostek organizacyjnych prokuratury, w tym w stanie spoczynku, a także dla asesorów prokuratorskich, adwokatów i aplikantów adwokackich, radców prawnych i aplikantów radcowskich, komorników sądowych, asesorów i aplikantów komorniczych oraz notariuszy, asesorów i aplikantów notarialnych (art. 1 proj. jsd.). Jednocześnie projekt przewidywał pozostawienie w poszczególnych ustawach niezmienionych przesłanek odpowiedzialności dyscyplinarnej, odrębnych dla każdego z zawodów prawniczych (art. 2 proj. jsd.) $)^{29}$. ED/\%24File/1202.pdf (data dostępu: 6.12.2016 r.).

25 Zob. Informacja Marszałka Sejmu RP do druku nr 1048 z dnia 6 lutego 2013 r., http://orka.sejm.gov.pl/Druki7ka. nsf/0/075720DD229758FBC1257B0F00390B9A/\%24File/1048-001.pdf (data dostępu: 6.12.2016 r.).

26 Zob. na temat projektu P. Czarnecki, Postępowanie dyscyplinarne..., op. cit., s. 423-424. Zob. także Stanowisko Rządu z 14 czerwca 2013 r. wobec poselskiego projektu ustawy o postępowaniu dyscyplinarnym wobec osób wykonujących niektóre zawody prawnicze (druk nr 1202), http://orka.sejm.gov.pl/Druki7ka.nsf/0/6F48CFBB29F497E7C1257B8F00362019/\%24File/1202-s.pdf (data dostępu: 6.12.2016 r.).

27 Zob. Informacja Marszałka Sejmu RP do druku nr 1202 z dnia 16 grudnia 2014 r., http://orka.sejm.gov.pl/Druki7ka.nsf/0/1A453B8F8ED93860C1257DB20031A269/\%24File/1202-005.pdf (data dostępu: 6.12.2016 r.).

28 Chociaż kwestia ta wydaje się nie być aż tak oczywista jak uznaje środowisko (zob. wypowiedź wiceministra sprawiedliwości M. Królikowskiego w toku debaty nad projektem, zrelacjonowaną przez „Gazetę Prawną" z 18 kwietnia 2013 r., która pozostaje jednak w wyraźnej sprzeczności ze stanowiskiem rządu wyrażonym w odpowiedzi na projekt ustawy w dniu 14 czerwca 2013 r.), wyraźnie zwraca na to natomiast uwagę A. Bojańczyk. Zob. A. Bojańczyk, Opinia do projektu..., op. cit. Zob. także wyrok Trybunału Konstytucyjnego z dnia 25 czerwca 2012 r., K 9/10, OTK-A 2012, nr 6, poz. 66 (Postępowanie przed Trybunałem toczyło się na skutek wniosku złożonego przez Rzecznika Praw Obywatelskich o zbadanie zgodności z Konstytucją przepisów regulujących zakres kontroli sądowej nad postępowaniami dyscyplinarnymi adwokatów, radców prawnych, notariuszy i prokuratorów. Trybunał Konstytucyjny podkreślił, że w obowiązującym w Polsce porządku konstytucyjnym dopuszczalne jest działanie innych niż sądy państwowe organów utworzonych w celu orzekania w postępowaniu dyscyplinarnym. Zdaniem Trybunału, obecny kształt postępowania kasacyjnego umożliwia rzeczywistą i efektywną kontrolę orzeczeń sądów dyscyplinarnych, dlatego też sądową kontrolę orzeczeń wydawanych w postępowaniach dyscyplinarnych adwokatów, radców prawnych, notariuszy i prokuratorów sprawowaną przez Sąd Najwyższy należy uznać za spełniającą tak standardy konstytucyjne, jak i konwencyjne).

29 Zdaniem projektodawców „[w] ten sposób zostanie poszanowana specyfika wykonywania danego zawodu prawniczego oraz zapewni się respektowanie określonych przez poszczególne grupy norm etyki zawodowej. Zachowana też zostanie powierzona konstytucyjnie samorządom zawodowym piecza nad wykonywaniem zawodu" (zob. Uzasadnienie projektu jednolitego sądownictwa dyscyplinarnego). 
Zgodnie z projektem, sądami dyscyplinarnymi miały stać się w pierwszej instancji sądy apelacyjne, w których w tym celu miały zostać utworzone wydziały dyscyplinarne, a w drugiej instancji - Sąd Najwyższy (art. 4 proj. jsd.). Właściwość sądu pierwszej instancji miała być wyznaczana poprzez miejsce pełnienia służby - w przypadku prokuratorów i sędziów lub siedziby - w przypadku adwokatów, radców prawnych, notariuszy i komorników sądowych (art. 5 proj. jsd.). Sędziami dyscyplinarnymi z mocy prawa mieliby stać się sędziowie danego sądu apelacyjnego, z wyjątkiem jego prezesa i wiceprezesów (art. 6 ust. 2 proj. jsd.).

Wobec projektu, zarówno w 2006 roku, jak i po jego ponownym zgłoszeniu, formułowano wiele argumentów krytycznych, jednak nie miały one charakteru bezwzględnego ${ }^{30}$. Podnoszono nawet, że skutek ujednolicenia $\mathrm{w}$ postaci likwidacji różnic pomiędzy odmiennymi modelami postępowań dyscyplinarnych być może pozwoliłby w przyszłości na wykształcenie jednolitej praktyki dyscyplinarnej ${ }^{31}$. Nie da się ukryć, że nastąpiłoby to bez wątpienia z korzyścią dla wszystkich zawodów prawniczych. Jednakże sam kształt rozwiązań zaproponowanych przez projektodawców został mocno skrytykowany. Według A. Bojańczyka „sądownictwo dyscyplinarne stanowi element «pieczy nad należytym wykonywaniem zawodu» zaufania publicznego"32. Przywoływano także orzecznictwo Trybunału Konstytucyjnego wskazujące, że zadaniem samorządu zawodowego jest „przestrzeganie właściwej jakości - w sensie merytorycznym i prawnym - czynności składających się na "wykonywanie zawodów»"33. Natomiast zgłoszony projekt całkowicie unicestwiał element samorządowy w postępowaniu dyscyplinarnym. Z kolei w stanowisku rządowym do projektu zwrócono uwagę, pomijając nawet wszelkie aspekty natury konstytucyjnej i celowościowej, że wprowadzenie jednolitego sądownictwa dla osób wykonujących niektóre zawody prawnicze musiałoby wiązać się z poważnymi skutkami społecznymi wynikającymi z przeniesienia całości sądownictwa dyscyplinarnego do kognicji sądów powszechnych i Sądu Najwyższego ${ }^{34}$. Oznaczałoby to automatyczne zwiększenie obciążenia tych organów dodatkowymi sprawami, a liczba toczących się co roku postępowań wszak nie jest mała ${ }^{35}$.

30 A. Bojańczyk wskazywał już w 2006 roku, że „zarówno z techniczno-prawnego, jak i ustrojowego punktu widzenia ujednolicenie modelu procesu dyscyplinarnego i stworzenie jednolitej ustawy postępowania dyscyplinarnego ma niewątpliwie sens i zasługuje na aprobatę" - A. Bojańczyk, W sprawie..., op. cit., s. 97-98. Zob. także Stanowisko Rządu z dnia 14 czerwca 2013 r..., op. cit., s. 2 (Wskazano po pierwsze, że „propozycja ta nie jest zgodna z wykładnią art. 17 Konstytucji RP i wynikającą z niej zasadą powierzenia samorządom pieczy nad wykonywaniem zawodów zaufania publicznego", a po drugie, że korporacyjne sądy dyscyplinarne posiadają wzorce zachowań etycznych związanych z właściwością danego zawodu prawniczego „i w znacznie większym stopniu potrafią zrozumieć i rozróżnić zachowania etyczne, którymi powinien cechować się jej członek"). lbidem, s. 98

Ibidem, s. 102.

Zob. wyrok TK z dnia 18 lutego 2004 r., P 21/02, ZU/OT K-A 2004, z. 2, poz. 9.

Stanowisko Rządu z dnia 14 czerwca 2013 r..., op. cit., s. 2.

Wobec notariuszy toczyło się w 2011 r. zaledwie 51 postępowań dyscyplinarnych, ale już wobec adwokatów w tym samym okresie 1337 (Stanowisko Rządu z dnia 14 czerwca 2013 r..., op. cit., s. 5-6). Na możliwe zwiększenie obciążenia sądów powszechnych zwracał uwagę także W. Marchwicki, Adwokackie postępowania dyscyplinarne - postrzeganie w opinii publicznej oraz propozycje zmian, (w:) A. Bodnar, P. Kubaszewski (red.), Postępowania dyscyplinarne w wolnych zawodach prawniczych, Warszawa 2013, s. 52. 
Model postępowania dyscyplinarnego wobec prokuratorów - wybrane zagadnienia

\section{Wnioski}

Obecnie obowiązujący model postępowania dyscyplinarnego wobec prokuratorów oparty na modelu „korporacyjnym” nadal wydaje się wymagać zmian. Jednym z jego problemów, obok innych wad, jak chociażby przedłużające się postępowania skutkujące nierzadko przedawnieniem przewinień dyscyplinarnych, jest kształt sądów dyscyplinarnych krytykowanych za ich „korporacyjność”, która może budzić pewne wątpliwości w zakresie obiektywizmu zapadających orzeczeń.

Modelowi temu, utrzymanemu przez nową ustawę Prawo o prokuraturze z 2016 r., przeciwstawić można model jednolitego sądownictwa dyscyplinarnego dla osób wykonujących niektóre zawody prawnicze. Propozycja ta, szeroko krytykowana za jej niekonstytucyjność, budzi także poważne wątpliwości związane z ewentualnym nadmiernym obciążeniem sądów apelacyjnych błahymi sprawami o charakterze dyscyplinarnym, które aktualnie rozpatrywane są przez korporacyjne komisje dyscyplinarne. Nawet pomimo tych argumentów, propozycja ta, mimo że interesująca i być może nawet przyszłościowa, nie może się ostać również ze względu na niejednolitość szkolenia prawników w ramach poszczególnych zawodów prawniczych oraz przede wszystkim odrębność ich obowiązków i wzorców etycznych, którymi mają się kiero$w \mathrm{c}^{36}$. Nie oznacza to oczywiście, że tam gdzie sądownictwo dyscyplinarne jest jednolite (taki model przyjmują np. Stany Zjednoczone), postępowania dyscyplinarne prowadzone wobec prokuratorów są $\mathrm{w}$ rzeczywistości częste i efektywne. Wręcz przeciwnie, należą one do absolutnej rzadkości, co często poddaje się krytyce ${ }^{37}$. Tym samym wydaje się, że stworzenie jednolitego sądownictwa dyscyplinarnego nie jest, samo w sobie, remedium na problemy postępowania dyscyplinarnego prowadzonego w Polsce przeciwko prokuratorom.

Dlatego też odpowiedzią na potrzeby reformy sądownictwa dyscyplinarnego prokuratorów, i częściowego chociaż zobiektywizowania orzecznictwa, wydaje się być propozycja „mieszanego” modelu sądownictwa dyscyplinarnego zgłoszona w 2014 roku, zgodnie z którą „korporacyjne” sądy dyscyplinarne orzekałyby w pierwszej instancji, natomiast w drugiej orzekać miałyby sądy apelacyjne (bądź Sąd Najwyższy). Być może do tego pomysłu warto powrócić. Taki kształt sądownictwa

36 Mimo że Autorka niniejszego opracowania w przeszłości wyrażała nadzieję co do możliwości rozważenia przyjęcia takiego modelu (K. Kremens, Odpowiedzialność..., op. cit., s. 18-19) i w dalszym ciągu uważa, że pomysł ten powinien budzić zainteresowanie oraz prowadzić do dyskusji nad modelem odpowiedzialności dyscyplinarnej osób wykonujących zawody prawnicze w Polsce, a w konsekwencji również nad kształtem edukacji prawniczej i zasadnością utrzymywania wyodrębnionych szkoleń dla reprezentantów różnych zawodów prawniczych, w chwili obecnej na gruncie obowiązującej treści art. 17 Konstytucji, wydaje się że brak jest jednak możliwości wprowadzenia takiego modelu.

37 Zob. m.in. D. Keenan, D.J. Cooper, D. Leibowitz, T. Lerer, The Myth of Prosecutorial Accountability After Connick v. Thompson: Why Existing Professional Responsibility Measures Cannot Protect Against Prosecutorial Misconduct, The Yale Law Journal Online 2011, nr 121, s. 203-265, a także o problemach z odpowiedzialnościa dyscyplinarną prokuratorów w odniesieniu nie tylko do Stanów Zjednoczonych Ameryki Północnej: R.F. Wright, M.L. Miller, The Worldwide Accountability Deficit for Prosecutors, „Washington \& Lee Law Review” 2010, vol. 9, nr 4, s. 1587-1620. 
dyscyplinarnego wobec prokuratorów realizowałby też w pełniejszym stopniu postulaty wyrażane $\mathrm{w}$ aktach prawa międzynarodowego dotyczących prokuratorów.

\section{BIBLIOGRAFIA}

Bojańczyk A., Opinia do projektu ustawy o postępowaniu dyscyplinarnym wobec osób wykonujących niektóre zawody prawnicze (druk sejmowy nr 970) z dnia 14 sierpnia $2007 \mathrm{r}$.

Bojańczyk A., W sprawie dwóch rozwiązań procesowych projektu ustawy o nowym ustroju dyscyplinarnym niektórych zawodów prawniczych, „Palestra” 2007, nr 9-10.

Czarnecki P., Postępowanie dyscyplinarne wobec osób wykonujących prawnicze zawody zaufania publicznego, Warszawa 2013.

Demendecki T., (w:) J. Bodio, G. Borkowski, T. Demendecki, Ustrój organów ochrony prawnej. Część szczegółowa, Wydanie 4, Warszawa 2013.

Kardas P., Rola i miejsce prokuratury w systemie organów demokratycznego państwa prawnego. Kilka uwag o przesłankach determinujących założenia projektu ustawy o prokuraturze, „Prokuratura i Prawo" 2012, nr 9.

Keenan D., Cooper D.J., Leibowitz D., Lerer T., The Myth of Prosecutorial Accountability After Connick v. Thompson: Why Existing Professional Responsibility Measures Cannot Protect Against Prosecutorial Misconduct, The Yale Law Journal Online 2011, nr 121.

Kozielewicz W., Odpowiedzialność dyscyplinarna sędziów, prokuratorów, adwokatów, radców prawnych i notariuszy, Warszawa 2012.

Kremens K., Jawność prokuratorskich postępowań dyscyplinarnych, „Prokuratura i Prawo” 2015, nr 5.

Kremens K., Odpowiedzialność zawodowa prokuratorów, Warszawa 2010.

Marchwicki W., Adwokackie postępowania dyscyplinarne - postrzeganie w opinii publicznej oraz propozycje zmian, (w:) A. Bodnar, P. Kubaszewski (red.), Postępowania dyscyplinarne w wolnych zawodach prawniczych, Warszawa 2013.

Świeczkowski K.K., Postępowanie dyscyplinarne wobec osób wykonujących zawody prawnicze, „Prokurator" 2006, nr 3.

Winczorek P., Stawecki T., Opinia prawna w sprawie zgodności z Konstytucją RP projektu ustawy o postępowaniu dyscyplinarnym wobec osób wykonujących niektóre zawody prawnicze z dnia 7 marca $2006 \mathrm{r}$.

Wright R.F., Miller M.L., The Worldwide Accountability Deficit for Prosecutors, „Washington \& Lee Law Review" 2010, vol. 9, $\mathrm{nr} 4$. 